\title{
CONTRIBUTION TO THE LIVERWORT FLORA OF THE REPUBLIC OF NORTH OSSETIA (NORTH CAUCASUS)
}

\author{
К ФЛОРЕ ПЕЧЕНОЧНИКОВ РЕСПУБЛИКИ СЕВЕРНАЯ ОСЕТИЯ \\ (СЕВЕРНЫЙ КАВКАЗ)
}

\author{
NADEZHDA A. KonstANTINOVA ${ }^{1}$, AnNA A. VILNET ${ }^{1} \&$ ANZHELla V. RUMYANTSEVA $^{2}$ \\ НАДЕЖДА А. КОНСТАНТИНОВА ${ }^{1}$, АННА А. ВИЛЬНЕТ ${ }^{1}$, АНЖЕЛЛА В. РУМЯНЦЕВА ${ }^{2}$
}

Abstract

Based on the identification of 60 samples collected by one of the authors, an annotated list of liverworts of the Alania National Park (North Caucasus, Republic of North Ossetia) was compiled for the first time. The list includes 27 species, the vast majority of which (19) were not previously known to the republic. The annotation for each species includes some synonyms, the presence of reproductive structures, habitat characteristics, a list of localities and associated species. The morphological features and distribution of rare in the Caucasus and little-known species are discussed. Based on publications and data obtained here, the list of species currently known for the Republic of North Ossetia including 52 species is provided. The oil bodies of Solenostoma caucasicum are described for the first time. GenBank accession numbers for seven species (nine samples) are given, a total of 17 accessions were deposited into GenBank.

Резюме

На основе идентификации 60 образцов, собранных одним из авторов, впервые составлен аннотированный список печеночников национального парка “Алания” (Северный Кавказ, Республика Северная Осетия). Список насчитывает 27 видов, подавляющее большинство из которых (19) ранее не были известны в республике. Краткие описания каждого вида включают в себя некоторые синонимы, наличие репродуктивных структур, характеристику местообитаний, перечисление местонахождений и сопутствующих видов. Обсуждаются морфологические особенности и распространение редких на Кавказе и малоизвестных видов. На основе публикаций и полученных данных составлен список видов, известных в настоящее время для республики Северная Осетия, насчитывающий 52 вида. Впервые дается описание масляных телец Solenostoma caucasicum. Приводятся номера Генбанка для семи видов (девяти образцов, 17 последовательностей), депонированных в Генбанк.

KEYWORDS: liverworts, distribution, habitats, morphology, GenBank accession numbers, Caucasus, Republic of North Ossetia, Russia

\section{INTRODUCTION}

The liverwort flora of the Caucasus has been studied very unevenly. One of the most poorly studied regions is the Republic of North Ossetia (Alania). As far as we know, the only published data on liverworts of this area are in Brotherus (1892). From the list given in Brotherus (1.c.), only 33 species are found in the territory of the Republic of Ossetia. The majority of specimens were collected by him along Georgian Military Road which runs almost along the eastern border of the republic. The list below is based on collections from the Alania National Park, located in western part of republic, an area called Western Digoria (Central Caucasus) near the border with the KabardinoBalkarian Republic (Fig. 1). Despite the fact that the collection of liverworts was carried out during a tourist trip and clearly does not reflect all the diversity of the flora of the area, the list includes 19 species that were not previously recorded for the Republic of North Ossetia, as well as several liverworts poorly known and rare in the Caucasus. Given the fact that the central part of Caucasus, where the described area is located, has been insufficiently studied, we believe that the publication of this list will be useful.

\section{STUDY AREA}

Western Digoria is located in Central Caucasus and bounded on the South by the Main Caucasian Ridge and on the North by the Sugan Ridge, which protects Digoria from cold Northern winds (Akhtyrchenko, 2015). The Tana-dor range divides Western Digoria into two main gorges: the Tana Gorge with the Tana-don River and the Khares Gorge (Kharessidon) with the Khares River (Kharessidon, Urukh) and its tributaries. The rivers are mainly

\footnotetext{
1 - Polar-Alpine Botanical Garden, Kola Sci. Centre, Russ. Acad. Sci., Kirovsk-6, Murmansk Province, 184256 Russia; e-mail: nadya50@list.ru; ORCID (NK): 0000-0002-7600-0512; (AV): 0000-0001-7779-2593.

2 - Cherepovets State University, Cherepovets, Vologda Province, 162600 Russia
} 


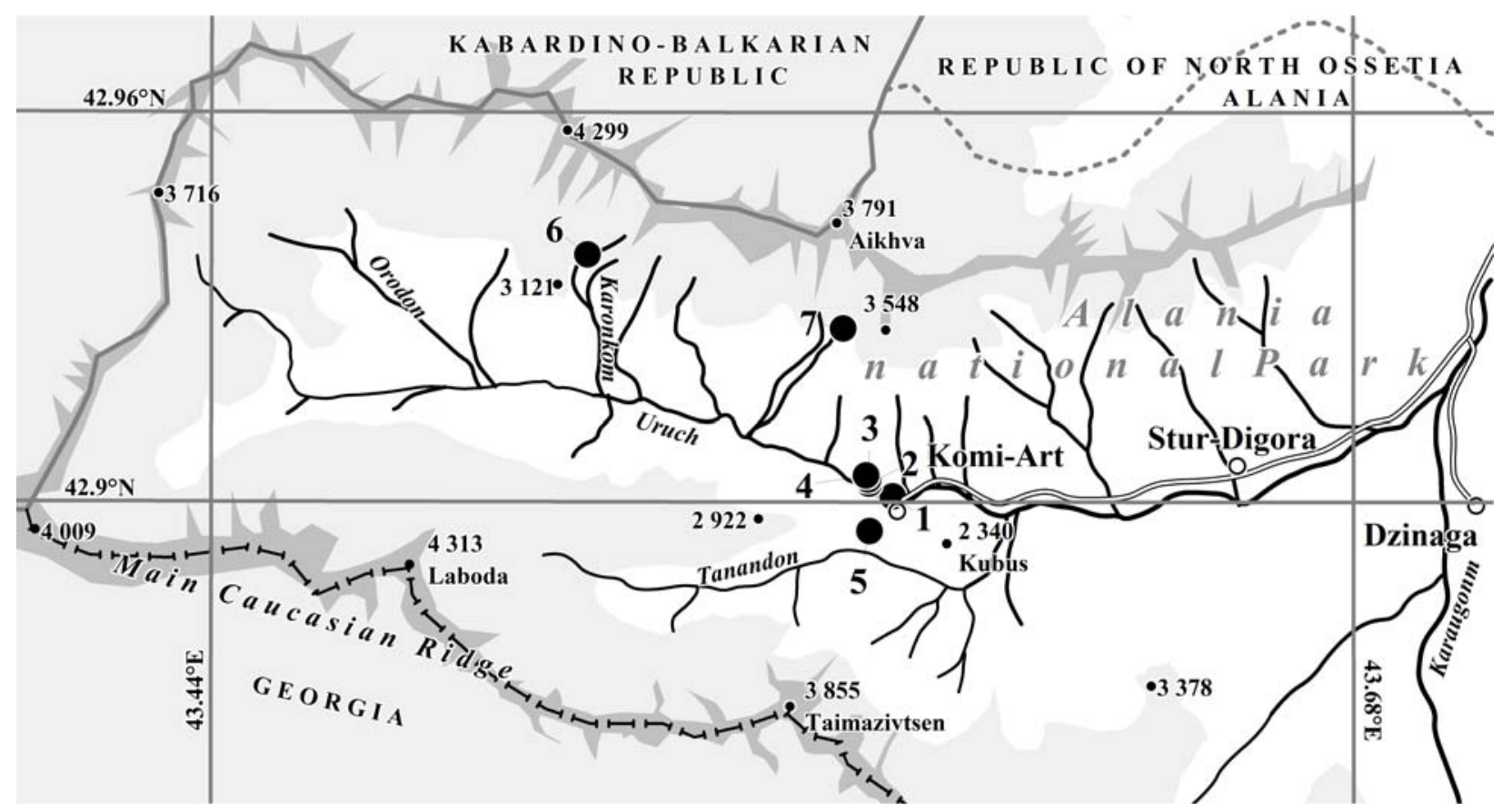

Fig. 1. Collecting sites.

1 - South facing slope at the base of Aykhva Mountain, $0.3 \mathrm{~km}$ to the north-west from Komy-Art mountaineering base, left bank of Urukh River, $42.900527^{\circ} \mathrm{N}-43.581026^{\circ} \mathrm{E}, 1850 \mathrm{~m}$ a.s.l.;

2 - South facing slope at the base of Aykhva Mountain, $1 \mathrm{~km}$ to the north-west from Komy-Art mountaineering base, $42.901868^{\circ} \mathrm{N}$ $-43.580742^{\circ} \mathrm{E}, 1950 \mathrm{~m}$ a.s.l.;

3 - South facing slope at the base of Aykhva Mountain, $1 \mathrm{~km}$ to the north-west from Komy-Art mountaineering base, between rocks, $42.901962^{\circ} \mathrm{N}-43.581182^{\circ} \mathrm{E}, 2000 \mathrm{~m}$ a.s.l.;

4 - South facing slope at the base of Aykhva Mountains, $1.1 \mathrm{~km}$ to the north-west from Komy-Art mountaineering base, $42.902151^{\circ} \mathrm{N}-43.581439^{\circ} \mathrm{E}, 2000 \mathrm{~m}$ a.s.l.;

5 - Between Kubus Mount (western slope) and Tana-dor Range, path in Tana Gorge, $0.7 \mathrm{~km}$ to the south-south-west from Komy-Art mountaineering base, Carex-Eriophorum-Sphagnum mire, $42.893623^{\circ} \mathrm{N}-43.577110^{\circ} \mathrm{E}, 2100 \mathrm{~m}$ a.s.1.;

6 - South slope at base of Galdor Mount, $3.7 \mathrm{~km}$ to the north from Komy-Art mountaineering base, $42.937070^{\circ} \mathrm{N}-43.515301^{\circ} \mathrm{E}$, 2960-3000 m a.s.l.;

7 - Upper Aykhvadon River, alpine meadow zone, $42.937070^{\circ} \mathrm{N}-43.515301^{\circ} \mathrm{E}, 2960 \mathrm{~m}$ a.s.1.

fed by glaciers. There are also smaller rivers, streams, waterfalls of various sizes and mountain peatlands, of which the largest are the Tana-dor (Kubus) swamp, located in the lower Tana-dor range, and the Chifandzar Swamp, located in the upper reaches of the Khares River.

The climate of Digoria is considered mild. The air temperature depends on the altitude, the average annual air temperature in the valley (ca. 1600-1700 $\mathrm{m}$ a.s.1.) is $3.2^{\circ} \mathrm{C}$, and above $2000 \mathrm{~m}$ (up to $3000 \mathrm{~m}$ ) up to $-6.1^{\circ} \mathrm{C}$. Precipitation is up to $950 \mathrm{~mm}$ per year in the basin, and up to $1400 \mathrm{~mm}$ per year at an altitude of more than $2000 \mathrm{~m}$; most of the precipitation falls in the summer. The complex topography of the mountains creates a special direction of air flow, so rain mostly occurs in the evening and at night. The average annual number of sunny hours is about 2250 (Akhtyrchenko, 2015; Alania. Physical and geographical characteristics http: // npalania.ru/index.php?id =126). In the valley, mountain forests are distributed up to a height of 2000-2200 m, mainly pine forests of Pinus sylvestris var. hamata Steven, less often forests of eastern beech (Fagus orientalis Lipsky), successively replaced by mountain birch forests (Betula litwinowii Doluch., B. raddeana Trautv.), crooked woodlands, juniper woodlands (with a predominance subspecies of Juniperus communis L.), thickets of Caucasian rhododendron (Rhododendron caucasicum Pall.), and then subalpine and alpine meadows, reaching up to $3000 \mathrm{~m}$.

\section{MATERIAL AND METHODS}

In summer of 2011 one of the authors (AR) gathered liverworts in National Park of Alania in the Urukh River basin. She managed to collect liverworts in seven areas (Figs.1, 2). Collections were made on the southern slope of the Aikhva mountain range (from 1850-2000 m up to $2960 \mathrm{~m}$ ), the southern slope (foot) of the Galdor mountains ("Galdorckie nochevki ", 2950-3100 m), and the Tana-dor ("Kubus") swamp $(2100 \mathrm{~m})$. The liverworts were collected in the following biotopes: pine forest; juniper woodlands; hazel tickets; birch-grass crooked forests; tall grass (herb-grass) meadow; alpine meadow; the edge of the snowfields (alpine heath); edges of swamps; banks of streams; wall of a narrow canyon. Liverworts were mainly restricted to rocky substrates, they less often occurred on soil, one sample was taken from the base 

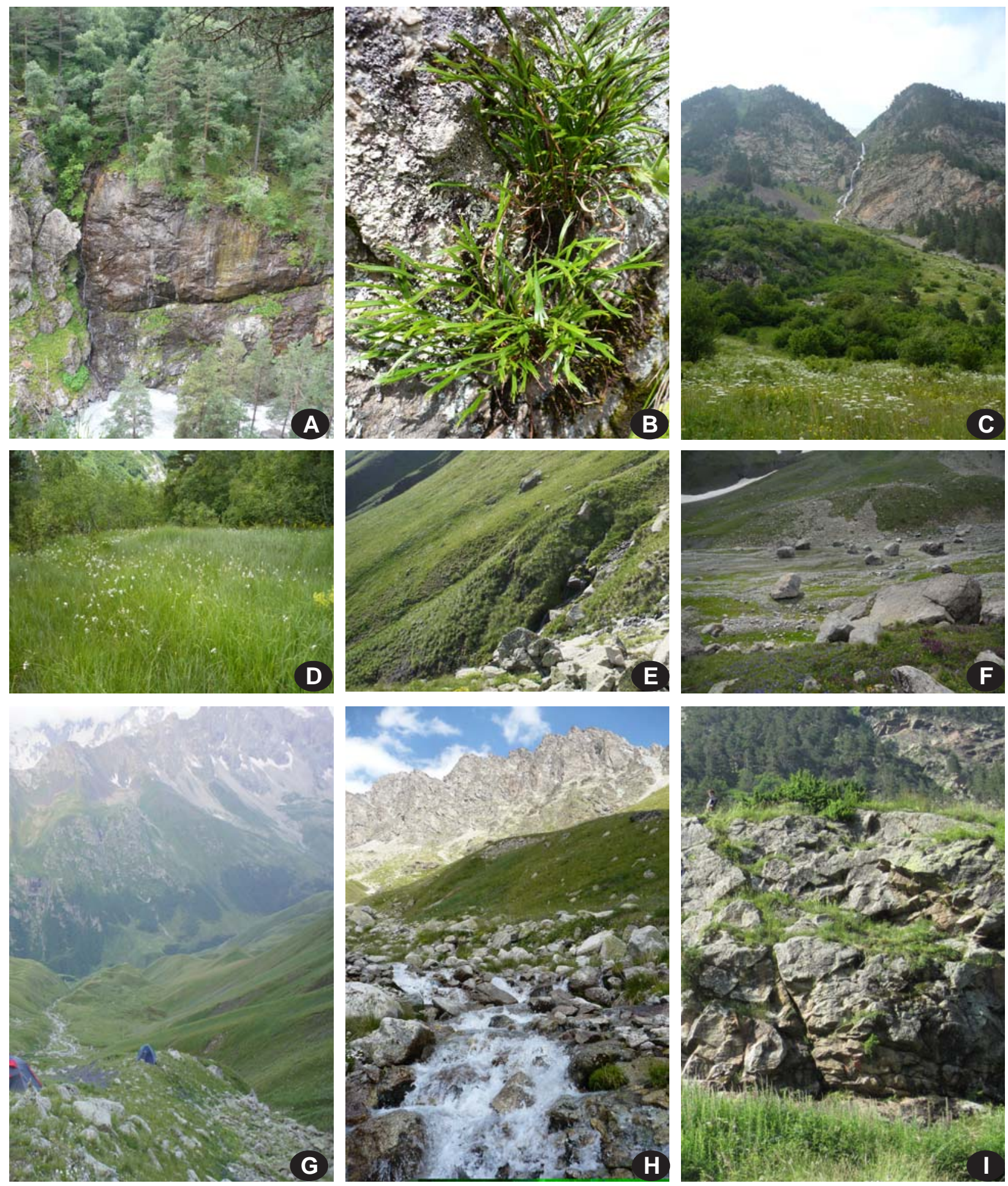

Fig. 2. A: Canyon of Urukh River, bank of Urukh River (locality 1); B: rock outcrop with Asplenium and liverworts in crevice, $1950 \mathrm{~m}$ a.s.l. (locality 2); C: the base of Aykhva Mountain (view of locality 4); D: Kubus mire, $2100 \mathrm{~m}$ a.s.l. (locality 5); E: rock outcrops in alpine meadow, south slope of Aykhva Mountain, $2960 \mathrm{~m}$ a.s.l. (locality 7); F: south slope at base of Galdor Mountain, 2960 m a.s.l. (locality 6); G: alpine meadow belt, 2960 m a.s.l. (locality 7); H: upper Aykhvadon River, 2960 m a.s.l. (locality 7); I: rock outcrops at $1950 \mathrm{~m}$ a.s.1. (locality 2).

of a birch trunk on the edge of a swamp. In total 60 specimens were collected. The coordinates were measured based on Google maps. Collecting localities are shown on the map (Fig.1).
The collected specimens were studied and identified in the laboratory of the Polar-Alpine Botanical GardenInstitute (Kirovsk, Murmansk Province) by the senior author. The exact determination was difficult for some 


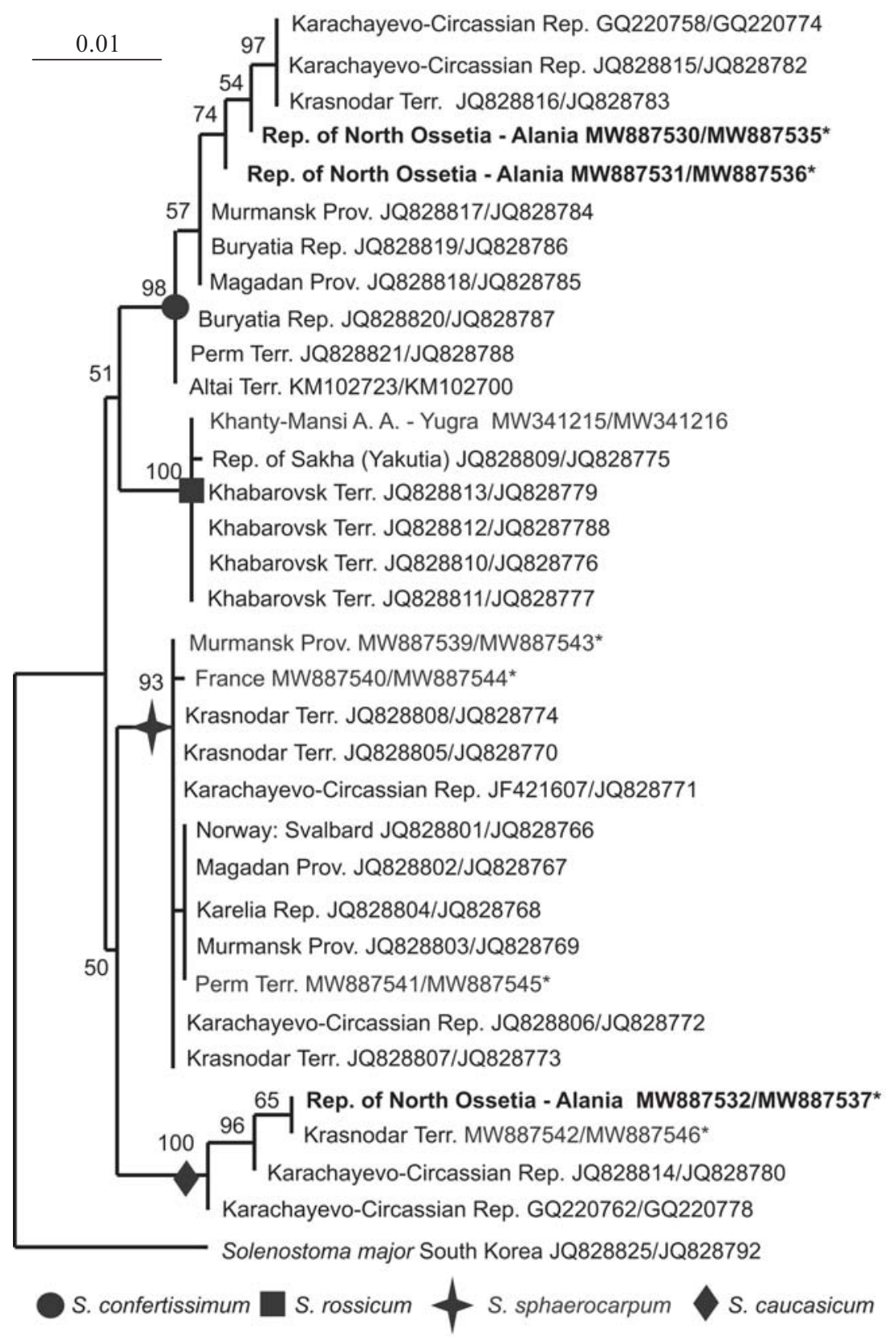

Fig. 3. Phylogram obtained in a maximum likelihood calculation for the selected species of the genus Solenostoma based on $\operatorname{trn} \mathrm{L}-\mathrm{F}+\operatorname{trn} \mathrm{G}-\mathrm{intron}$ dataset. Bootstrap support values more than $50 \%$ are indicated. The GenBank accession numbers $\operatorname{trn} \mathrm{L}-\mathrm{F} /$ $\operatorname{trn} \mathrm{G}$-intron are provided. Firstly published accessions are marked by asterisk, accessions from Alania are in bold.

samples due to the lack of sufficient features, for example gametangia (e.g. Frullania, Solenostoma, Jungermannia), gemmae (Scapania), oil bodies (Lophozia), so ITS1-2 nrDNA, $\operatorname{trn} \mathrm{L}-\mathrm{F}$ or $\operatorname{trn} \mathrm{G}$-intron were sequenced to compare with previously obtained datasets. DNA was extracted from dried liverwort tissue with DNeasy Plant Mini Kit (Qiagen, Germany). The primers for amplification and sequencing followed White et al. (1990) for ITS1-2, Taberlet et al. (1991) for trnL-F, and Shaw et al. (2005) for trnG-intron. PCR were carried out in $20 \mu \mathrm{l}$ volumes with the following amplification cycles: $3 \mathrm{~min}$ at $94^{\circ} \mathrm{C}$, 30 cycles $\left(30 \mathrm{~s} 94^{\circ} \mathrm{C}, 40 \mathrm{~s} 58^{\circ} \mathrm{C}\right.$ (ITS1-2, trnL-F) or $64^{\circ} \mathrm{C}$ (trn G-intron), $60 \mathrm{~s} 72^{\circ} \mathrm{C}$ ) and 2 min of final extension time at $72^{\circ} \mathrm{C}$. Amplified fragments were visualized on $1 \%$ agarose TAE gels by EthBr staining, purified using the QIAquick Gel Extraction Kit (Qiagen, Germany), and then used as a template in sequencing reactions with the ABI Prism BigDye Terminator Cycle Sequencing Ready Reaction Kit (Applied Biosystems, USA) following the standard protocol provided for Applied Biosystems 3730 DNA Analyzer (USA) in Genome-Centre (Moscow).

Seventeen nucleotide sequences were assembled in BioEdit 7.0.1 (Hall, 1999), tested by BLAST search (https://blast.ncbi.nlm.nih.gov/Blast.cgi) and then included in the appropriate datasets for genera Jungermannia, 
Solenostoma, Scapania, Frullania, Lophozia, and Pellia to check infraspecific variability in Mega 5.1 (Tamura et al., 2011) using the pairwise deletion option for counting gaps. All newly generated sequences were deposited into GenBank, accession numbers are provided in Annotated list of species. Phylogenetic estimation by maximum likelihood (ML) in PhyML v.3.0 (Guindon et al., 2010) with $\mathrm{HKY}+\mathrm{G}+\mathrm{I}$ as the best-fit evolutionary model of nucleotide substitutions model selected by ModelGenerator software (Keane et al., 2006) and 350 bootstrap replications suggested by RAxML v7.2.6 (Stamatakis, 2006) were implemented for 34 specimens of the genus Solenostoma to clarify affinity and taxonomic position of the poorly known species $S$. caucasicum. The taxa were sampled according with known phylogeny for the genus Solenostoma (Bakalin et al., 2014); previously obtained eight nucleotide sequences for four Solenostoma spp. accessions are first published here as well.

The studied specimens are deposited in Herbarium of Polar-Alpine Botanical Garden-Institute of the Kola Scientific Center, Russian Academy of Sciences (KPABG). Label data are incorporated in the Information System L (https://isling.org), associated with KPABG .

\section{ANNOTATED LIST OF SPECIES}

The annotated list of liverworts is given in alphabetical order. It includes 27 species, 19 of which are new for North Ossetia. The nomenclature follows Hodgetts et al. (2020). Brief descriptions of each species include synonyms that were given in Brotherus (1892). After the species name the presence of reproductive structures is given in parentheses (and. - androecia; gyn. - gynoecia; per. - perianths or pseudoperianths; spor. - sporophytes; gem. - gemmae). The collecting sites are listed according to Fig. 1, followed (in parentheses) by the number of specimens in herbarium KPABG. The main associated species are listed in descending order of frequency of occurrence with the corresponding species. At least one reference to the herbarium number in the Information System - CRIS (recently under the symbol L., https:// isling.org/hepatics) is cited (in brackets). For sequenced samples, the Genbank accession numbers are given. An asterisk before a species name means a new record for North Ossetia.

*Anthelia juratzkana (Limpr.) Trevis. -6 (11): on bank of brook, [123169]. On soil in snow bed, Primula-Carex-Cetraria meadow, on soil.

Barbilophozia barbata (Schmidel ex Schreb.) Loeske - 5 (15): on soil, boulders and at base of Betula in Carex-Eriophorum-Sphagnum mire.

*B. hatcheri (A. Evans) Loeske (gem., and.) - 5 (17): CarexEriophorum-Sphagnum mire, on soil and rock, at base of Betula; 6: Primula-Carex-Cetraria meadow, on soil; 7: on soil between rocks.

*B. lycopodioides (Wallr.) Loeske - 5 (2): on rock in CarexEriophorum-Sphagnum mire, some shoots among Barbilophozia barbata [123123].

Blepharostoma trichophyllum (L.) Dumort. -5 (2): on soil and boulder in Carex-Eriophorum-Sphagnum mire, scattered in mats dominated by Scapania irrigua [123124] or in mats dominated by Lophocolea minor [123145].

*Cephalozia ambigua C. Massal. - 6 (1): on bank of brook on fine earth in snowbed, single shoots in mats dominated by Anthelia juratzkana [123169].

*Cephaloziella cf. varians (Gottsche) Steph. - 7 (1): on soil between rocks [123163], single shoots in mats dominated by Lophozia wenzelii with an admixture of Anthelia juratzkana. *Conocephalum salebrosum Szweyk., Buczk. \& Odrzyk. - 7 (2): on rock at base of moist cliff [123117], in pure mats. Conocephalum conicum (L.) Dumort. was previously recorded for the Republic of North Ossetia by Brotherus (1892) as Fegatella conica (L.) Cord. Conocephalum salebrosum was described more than a century later (Szweykowski et al., 2005). Both species are widespread in Caucasus and most likely both species occur in North Ossetia.

*Frullania caucasica Steph. - 1 (1): in gorge, on rock, in pure mats [123113]; 2 (4): on rocks in alpine meadow, in pure mats [123114: MW872335 (ITS1-2), MW351733 (trnL-F); 123116: MW358446 (ITS1-2), MW351732 (trnL-F)].

*Fuscocephaloziopsis pleniceps (Austin) Váňa et L. Söderstr. - 6 (4): on bank of brook (upper reach of Karonkom River), in pure mats [123175] or in mats with admixture of Nardia geoscyphus[123157], Anthelia juratzkana, Lophozia ventricosa var. longiflora.

*Jungermannia polaris Lindb. (per., and., spor.) - 6 (1): on bank of mountain brook [123174: MW887529 (trnL-F), MW887538 (trnG-intron)], net on sandy soil.

*Lophocolea minor Nees. (gem.) - 5 (4): on boulder in mire [123145], in mats with Blepharostoma trichophyllum, Scapania irrigua, Radula complanata, Plagiochila porelloides.

*Lophozia lantratovae Bakalin (gem.) - 5 (2): on rock on spring bank, some shoots mixed with Solenostoma caucasicum [123153: MW872337 (ITS1-2), MW887533 (trnL-F)]. As suggested by A. Hagborg (pers. comm.), despite the author of description spells L. lantratoviae Bakalin, the correct genitive derived from Lantratova is lantratovae. This is a correctable error according ICN Art. 60.8(a).

*L. ventricosa (Dicks.) Dumort. var. longiflora (Nees) Macoun - 6 (2): on bank of brook (upper reach of Karonkom River) dominating in mats with admixture of Fuscocephaloziopsis pleniceps and Anthelia juratzkana [123158] and single shoots in mats dominated by Scapania irrigua [123143].

*L. wenzelii (Nees) Steph. (gem.) - 6 (5): on soil in snowbed in mats with admixture of Anthelia juratzkana, Cephaloziella cf. varians, Scapania obcordata [123163, 123170] or as single shoots in mat dominated by Scapania obcordata [123166: MW887534 (trnL-F)] and Anthelia juratzkana [123167].

Metzgeria furcata (L.) Dumort. - 5 (2): at base of Betula [123128], single shoots in mat dominated by Radula complanata and on rocks of edge of mire, single shoots in mat dominated by Radula complanata [123135]

Nardia geoscyphus (De Not.) Lindb. (per, and., spor.) - 6 (2): on bank of brook (upper reach of Karonkom River), in mats with admixture of Fuscocephaloziopsis pleniceps [123159, 123157].

*Pellia neesiana (Gottsche) Limpr. - 5 (2): on rock on spring bank with Scapania subalpina [123151]; 6: on soil on bank of brook, in pure mats [123161: MW872336 (ITS1-2), MW887528 (trnL-F)].

Plagiochila porelloides (Torr. ex Nees) Lindenb. - 5 (7): on rocks and boulders in Carex-Eriophorum-Sphagnum mire, 
Table. 1. The value of infrageneric and infraspecific $p$-distances for selected Solenostoma species.

Taxon

Infraspecific $p$-distances

$\operatorname{trn} \mathrm{L}-\mathrm{F} / \operatorname{trn} \mathrm{G}$-intron, \%

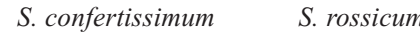 \\ $1.3 / 0.5$ \\ $1.4 / 1.1$ \\ $2.2 / 1.0$ \\ $0.9 / 1.0$ \\ $2.1 / 1.2$
}

Infrageneric $p$-distances,

S. sphaerocarpum S. caucasicum
$1.6 / 1.2$
S. confertissimum
S. rossicum
S. sphaerocarpum
S. caucasicum

$0.3 / 0.2$

$0.0 / 0.0$

$0.1 / 0.0$

$0.4 / 0.1$ in almost pure mats [123134] or mixed with Radula complanata, Barbilophozia hatcheri, B. barbata, Lophocolea minor, Sphenolobus minutus, Scapania irrigua, Blepharostoma trichophyllum.

Porella platyphylla (L.) Pfeiff. (and.) - 4(1): on rock in Corylus avellana thickets, in pure mats [123121].

Radula complanata (L.) Dumort. (per, and., gem.) - 3, 4, 5 (18): Between rocks and on rocks (schists) in crevices under Juniperus tickets, on rock (schists) in crevice, on rock (shale) in pine forest, on soil, rocks and at base of Betula in CarexEriophorum-Sphagnum mire, on rock on spring bank, in pure mats [123126] or mixed with other liverworts, more often with Barbilophozia barbata, B. hatcheri.

*Scapania irrigua (Nees) Nees - 5 (4): in Carex-EriophorumSphagnum mire, on soil, mostly in pure mats [123124] or mixed with Blepharostoma trichophyllum, Radula complanata, Plagiochila porelloides, Lophozia ventricosa var. longiflora, Lophocolea minor.

${ }^{*} S$. cf. obcordata (Berggr.) S.W. Arnell - 6(4): on soil in snowbed [123166].

*Solenostoma caucasicum (Váňa) Konstant. - 5 (2): on rock on spring bank [123152: MW887532 (trnL-F), MW887537 (trnG-intron), 123153]. Oil-bodies (3)4-6 per cell, light grey, $5 \times 5-7 \mu \mathrm{m}$, leaves obliquely inserted, cordate $830 \times 800 \mu \mathrm{m}$, cuticle distinctly papillose. In small mats with admixture of single shoots of Lophozia lantratovae.

*S. confertissimum (Nees) Schljakov (gyn., per., and.) - 6 (4): on bank of brook, on rocky soil, in pure mats [123160: MW887531 (trnL-F), MW887536 (trnG-intron)] or mixed with mosses [123156: MW887530 (trnL-F), MW887535 (trnG-intron)].

*Sphenolobus minutus (Schreb.) Berggr. - 5 (3): in Carex-Eriophorum-Sphagnum mire, on boulder [123139], in all specimens mixed with other liverworts: Barbilophozia hatcheri, B. barbata, Plagiochila porelloides.

Trilophozia quinquedentata (Huds.) Bakalin (per.) - 5 (3): on boulders in Carex-Eriophorum-Sphagnum mire, in pure mats [123146] or with Radula complanata.

\section{DisCUSSION}

In total, we recorded 27 species, the vast majority of which (19) were not previously known for the republic. The largest number of new records was collected at altitudes of about $3000 \mathrm{~m}$ a.s.l. Some of these species are rather widespread at high altitudes in the Caucasus arcticmontane (e.g. Anthelia juratzkana, Cephalozia ambigua) or arcticboreomontane (e.g. Barbilophozia hatcheri, Fuscocephaloziopsis pleniceps, Lophozia wenzelii, L. ventricosa var. longiflora, Pellia neesiana, Scapania irrigua, Solenostoma confertissimum, Sphenolobus minutus) liverworts, that were recorded in Krasnodar Territory and Republic of Adygeya (Konstantinova \& Savchenko, 2009), Kabardino-Balkarian Republic (Potemkin \&
Doroshina, 2009), Republic of Daghestan (Konstantinova, 2011). Some of the recorded liverworts are widely distributed in the forest and subalpine zones of the Caucasus (Barbilophozia barbata, Metzgeria furcata, Plagiochila porelloides, Radula complanata). At the same time, most of the species collected by Brotherus (1892) near the eastern border of the republic were not collected by AR. These are also mostly widespread species in the Caucasus. As a result, 50 species have been identified in the Republic of North Ossetia (Appendix), which, of course, does not reflect the true diversity of the flora of the republic and indicates the need for further study.

Along with the species widely distributed in Caucasus, several rare and poorly studied ones have been found that deserve special discussion.

The most interesting is the finding of Solenostoma caucasicum. The collected plants are light to yellowish or brownish green, especially in old parts of plants, have obliquely inserted, concave, cordate in plan leaves with distinctly papillose cuticle and relatively large cells that fit well the original description of Ván̆a (1970). In the studied samples, oil bodies were preserved, which made it possible to describe them for the first time (see above). Current phylogenetic estimation of the genus Solenostoma resulted in a tree with Log likelihood -2058.085, topology of which corresponds with previously published ones (Bakalin et al., 2014): four tested specimens of $S$. caucasicum composed a clade in a poorly supported relation to $S$. sphaerocarpum (Fig. 3). The infraspecific variability of $S$. caucasicum is $0.4 \%$ in $t r n \mathrm{~L}-\mathrm{F}$ and $0.1 \%$ in $\operatorname{trn} \mathrm{G}$-intron, which corresponds to the level of infraspecific variability in $S$. sphaerocarpum, S. confertissimum and $S$. rossicum (Table 1). The level of sequence divergence in $S$. caucasicum from the cited species is $1.6-$ $2.2 \%$ in $\operatorname{trn} \mathrm{L}-\mathrm{F}$ and $1.0-1.2 \%$ in $\operatorname{trn} \mathrm{G}$-intron that is $1.5-$ 2 times higher than between $S$. sphaerocarpum, S. confertissimum and $S$. rossicum. The obtained data clearly suggest that $S$. caucasicum is a robust species. Solenostoma caucasicum was reported by Ván̆a (1970) for Georgia from almost sea level in Batumi from where the species was described and also in Turkey, where the species is found up to an altitude of $2000 \mathrm{~m}$. In the Russian part of Caucasus this species was previously reported from the Republic of Karachayevo-Circassian: Teberda River Basin, Klukhor River valley at 1900 m a.s.l. (Konstantinova \& Savchenko, 2013). The species is found as well in Krasnodar Territory, Chugush Ridge, southern slope of Chugush Mount (K468-1-12) at altitude about $2000 \mathrm{~m}$. 
Another species that deserves attention is Lophozia lantratovae. This species was described from the mountains of South Siberia (Bakalin, 2005) and was then found in most of the mountain ridges of South Siberia, in the Far East of Russia as well as in the Korean Peninsula (Choi et al., 2012), Japan and China (Bakalin, pers. comm.). The species has previously been reported in the Caucasus for two sites in the Teberda Strict Nature Reserve (Ignatova et al., 2008) and Georgia (Bakalin \& Tigishvili, 2013) but specimens from the Caucasus were not sequenced. Study of two DNA loci among five previously sequenced specimens from Primorsky Territory, Republic of Buryatia and China found that specimen from Alania shows differences by $0.4-1.1 \%$ in ITS1-2 and 0 $0.2 \%$ in $\operatorname{trn} \mathrm{L}-\mathrm{F}$ that corresponds with level of infraspecific variation in Lophozia (Konstantinova et al., 2020). Caucasus is at present the westernmost outpost of the distribution of this species.

One of the species first recorded in the Republic of North Ossetia is Jungermannia polaris. The species has previously been reported for Caucasus only from the Gunib Plateau, Republic of Dagesthan (Potemkin \& Urbanavichus, 2010). The second finding of the species evidences, apparently, its sporadic distribution under suitable conditions in the still very poorly studied highlands of the Caucasus. Molecularly, the species differs from samples from close to the type locality in Svalbard (0.6$0.7 \%$ in $\operatorname{trn} \mathrm{L}-\mathrm{F}, 1.4-1.6 \%$ in $\operatorname{trn} \mathrm{G}$-intron) and it is a little bit higher than was shown as infraspecific in Jungermannia (Konstantinova \& Vilnet, 2016).

Of great interest are several specimens of Frullania caucasica collected from rocks in subalpine meadows. Unlike most of the known specimens from Caucasus, collected mostly on bark in the samples from the Republic of North Ossetia, caducous leaves are very weakly expressed. The study of several loci showed that these plants are quite similar to representatives from other regions of Caucasus $(0-0.2 \%$ in ITS $1-2,0.8 \%$ in trnL-F).

Combining all available data, the liverwort flora of the Republic of North Ossetia includes 52 species (Appendix). This is surely far below the actual number of species present in the republic and further research of the liverwort flora of the republic remains extremely relevant.

\section{ACKNOWLEDGMENTS}

Anders Hagborg is gratefully acknowledged for correction of English and useful suggestions. A. Savchenko is kindly thanked for preparing the map of the studied area. We are grateful to Galina Doroshina who clarified to us which of the Brotherus collection sites are located in North Ossetia. We also thank V.A. Bakalin and E.A. Ignatova for his comments. This study was carried out in the framework of the State Research Program of the Polar-Alpine Botanical Garden and Institute KSC RAS (AAAA-A18- 118050490088-0) and was partly supported by RFBR (№18-04-00594).

\section{LITERATURE CITED}

[ABRAMOVA, A.L. \& I.I. ABRAMOV] АБРАМОВА А.Л., И.И. АБРАМОВ. 1953. Материалы к флоре печеночных мхов ЮгоОсетии. - [Materials to the liverwort flora of the South Ossetia] Tpyды ботанического института им. В.Л. Комарова Академии наук CCCP, cep. 2 [Trudy Botanicheskogo Instituta im. V.L. Komarova Akademii Nauk SSSR, ser. 2] 8: 375-401.

[AKHTYRCHENKO, G.V.] AХTЫРЧЕНКО Г.В. 2015. Дигория. Маршруты на горные вершины. - [Digoria. Mountain routes] M. [Moscow], 400 pp.

[BAKALIN, V.A.] БАКАЛИН В.А. 2005. Монографическая обработка рода Lophozia (Dumort.) Dumort. s. str. - [The monographic study of Lophozia (Dumort.) Dumort. s. str.] M., Наука [Moscow, Nauka], $238 \mathrm{pp}$.

BAKALIN, V.A. \& K. TIGISHVILI. 2013. Notes of Lophozia VII. On the distribution of some species of Lophozia in Georgia (Caucasus). Arctoa 22: 121-123.

BAKALIN, V.A., A.A. VILNET, T. FURUKI \& T. KATAGIRI. 2014. Taxonomic Novelties in Solenostoma-Plectocolea Complex (Solenostomataceae, Hepaticae) in East Asia. - Botanica Pacifica 3: 3-18. http://botsad.ru/media/aux/bp/BP_2014_3_2_bakalin\&vilnet.pdf

CHOI, S.S., V.A. BAKALIN , CH.H. KIM, B.YU. SUN. 2012. Unrecorded liverwort species from Korean flora. - Korean Journal of Plant Taxonomy 42(1): 80-90. doi:https://doi.org/10.11110/kjpt.2012.42.1.080

BROTHERUS, V.F. 1892. Enumeratio muscorum Caucasi. - Acta Societatis Scientiarum Fennicae 19(12): 1-170.

HALL, T.A. 1999. BioEdit: a user-friendly biological sequence alignment editor and analysis program for Windows 95/98/NT. - Nucleic Acids Symposium Series 41: 95-98.

[IGNATOVA, E.A., M.S. IGNATOV, N.A. KONSTANTINOVA, V.I. ZOLOTOV \& V.G. ONIPCHENKO] ИГНАТОВA Е.A., М.С. ИГНАТОВ, Н.А. КОНСТАНТИНОВА, В.И. ЗОЛОТОВ, В.Г. ОНИПЧЕНКО. 2008. Флора мохообразных Тебердинского заповедника. - [Bryophytes of Teberdinskiy State Nature Reserve] Флора и фауна заповедников [Flora i fauna zapovednikov] 112: 1-86.

GUINDON, S., J.F. DUFAYARD, V. LEFORT, M. ANISIMOVA, W. HORDIJK \& O. GASCUEL. 2010. New Algorithms and Methods to Estimate Maximum-Likelihood Phylogenies: Assessing the Performance of PhyML 3.0. - Systematic Biology 59: 307-321.

KEANE, T.M., C.J. CREEVEY, M.M. PENTONY, T.J. NAUGHTON \& J.O. MCINERNEY. 2006. Assessment of methods for amino acid matrix selection and their use on empirical data shows that ad hoc assumption for choice of matrix are not justified. - BMC Evolutionary Biology 6: 29 .

KONSTANTINOVA, N.A. \& A.N. SAVCHENKO. 2013. Russian Caucasus distribution of fourteen hepatics rare and threatened in Europe. Polish Botanical Journal 58: 573-584.

KONSTANTINOVA, N.A. \& A.A. VILNET. 2016. A new species of the genus Jungermannia (Jungermanniales, Marchantiophyta) from the Caucasus with notes on taxa delimitation and taxonomy of Jungermannia s. str. - Phytotaxa 255: 227-239. http://www.mapress.com/j/ pt/article/view/phytotaxa.255.3.4/5469

KONSTANTINOVA, N.A., A.A. VILNET \& YU. S. MAMONTOV. 2020 A new species of the genus Lophozia (Lophoziaceae) from the Svalbard archipelago. - Arctoa 29: 124-134. doi: 10.15298/arctoa.29.10.

[POTEMKIN, A.D. \& G.YA. DOROSHINA] ПОТЕМКИН А.Д., Г.Я. ДОРОШИНА. 2009. К флоре печеночников российской части Кавказа. - [To the liverwort flora of the Russian part of the Caucasus] Новости систематики низших растений [Novosti Sistematiki Nizshikh Rastenij] 43: 377-392.

[POTEMKIN, A.D. \& G.P. URBANAVICHUS] ПОТЕМКИН А.Д., Г.П.УРБАНАВИЧЮС. 2010. Новые находки печеночников в Республике Дагестан. 1. - [New livervort records from Republic of Dagestan] - Arctoa: 19: 273-274.

SHAW, J., E.B. LICKEY, J. BECK, S.B. FARMER, W. LIU, J. MILLER, K.C. SIRIPUN, C. WINDER, E.E. SCHILLING \& R.L. SMALL. 2005. 
The tortoise and the hare II: relative utility of 21 noncoding chloroplast DNA sequences for phylogenetic analysis. - American Journal of Botany 92: $142-166$.

STAMATAKIS, A. 2006. RAxML-VI-HPC: Maximum Likelihood-based Phylogenetic Analyses with Thousands of Taxa and Mixed Models. Bioinformatics 22: 2688-2690.

TABERLET, P., L. GIELLY, G. PAUTOU \& J. BOUVET.1991.Universal primers for amplification of three non-coding regions of chloroplast DNA. - Plant Molecular Biology 17: 1105-1109.

TAMURA, K., D. PETERSON, N. PETERSON, G. STECHER, M. NEI \& S. KUMAR. 2011. MEGA 5: Molecular Evolutionary Genetics Analysis Using Maximum Likelihood, Evolutionary Distance, and Maximum Parsimony Method. - Molecular Biology and Evolution 28: 2731-2739.

VÁŇA, J. 1970. Jungermannia caucasica sp. n. - Preslia 42: 96-97.

WHITE, T.J., T. BRUNS, S. LEE \& J. TAYLOR. 1990. Amplification and direct sequencing of fungal ribosomal RNA genes for phylogenetics. - In: Innis, M.A., Gelfand, D.H., Snisky, J.J. \& White, T.J. (eds.) PCR protocols: a guide to methods and applications. San Diego, pp. $315-322$.

\section{APPENDIX}

THE LIST OF LIVERWORTS OF THE REPUBLIC OF NORTH OSSETIA (! - SPECIES LISTED IN THIS STUDY)

Anthelia juratzkana (Limpr.) Trevis. !

Barbilophozia barbata (Schmidel ex Schreb.) Loeske !

B. hatcheri (A.Evans) Loeske !

B. lycopodioides (Wallr.) Loeske ! + Brotherus (1892): "in monte Kasbek", as Jungermannia lycopodioides

Bazzania tricrenata (Wahlenb.) Lindb. - Brotherus (1892): "ad mare glaciale Zei”, as Bazzania triangularis (Schleich.) Lindb.

Blepharostoma trichophyllum (L.) Dumort. ! + Brotherus (1892): "in monte Kasbek".

Cephalozia ambigua C.Massal. !

Cephaloziella cf. varians (Gottsche) Steph. !

Clevea hyalina (Sommerf.) Lindb. - Brotherus (1892): "Balta, ad fl. Terek ad mare glaciale Zei”.

Conocephalum conicum (L.) Dumort. - Brotherus (1892): “in monte Lagermanzech ad fl. Didi Liachva, Balta, Lars et Kobi ad fl. Terek", as Fegatella conica (L.) Cord.

C. salebrosum Szweyk., Buczk. \& Odrzyk. !

Frullania caucasica Steph. !

F. dilatata (L.)Dumort. - Brotherus (1892): "Vladikavkas, Balta et Lars ad fl. Terek"

F. tamarisci (L.) Dumort. - Brotherus (1892): "Lars et Kobi ad fl. Terek".

Fuscocephaloziopsis connivens(Dicks.) Váňa \& L.Söderstr. Brotherus (1892): “Kobi ad fl. Terek", as Cephalozia multiflora.

F. pleniceps (Austin) Váňa et L.Söderstr. !

Jungermannia atrovirens Dumort. - Brotherus (1892): "Lars ad fl. Terek", as Jungermannia riparia Tayl.

J. polaris Lindb. !

Lejeunea patens Lindb. - Brotherus (1892): "Lars ad fl. Terek ad rupes schistosas regionis silvaticae media".

Lepidozia reptans (L.) Dumort. - Brotherus (1892): “ad mare glaciale Zei".

Lophocolea minor Nees. !

Lophozia lantratovae Bakalin!

L. ventricosa (Dicks.) Dumort. var. longiflora (Nees) Macoun! L. wenzelii (Nees) Steph.!

Mannia androgyna (L.) A.Evans - Brotherus (1892): "Lars et Kobi ad fl. Terek in fissuris humosis rupium regionis silvaticae media et superioris" as Grimmaldia dichotoma Raddi.
M. fragrans (Balb.) Frye \& L.Clark - Brotherus (1892): "Balta, Lars, pr. pagum Kasbek et pr. Kobi ad fl. Terek in fissuris humosis rupium regionis silvaticae media et superioris", as Grimmaldia fragrans (Balb.) Cord.

Marchantia quadrata Scop. - Brotherus (1892): "in monte Lagermanzech ad fl. Didi Liachva, Lars, Kasbek et Kobi ad fl. Terek", as Chomiocarpon quadratus (Scop.) Lindb.

Mesoptychia collaris (Nees) L.Söderstr. \& Váña - Brotherus (1892): "Balta, ad fl. Terek, Kasbek, ad pagum et in reg. alp., Gudgora ad fonts fl. Aragva”, as Jungermannia Muelleri Nees.

Metzgeria conjugata Lindb. - Brotherus (1892): "Khtsoue ad fl. Didi Liachva,, Lars et Kobi ad fl. Terek”.

M. furcata (L.) Dumort. - ! + Brotherus (1892): "Balta, ad fl. Terek".

Nardia geoscyphus (De Not.) Lindb. - !+Brotherus (1892): "in monte Kasbek, reg. alp., Kobi ad fl. Terek", as Nardia haematosticta (Nees) Lindb.

Neoorthocaulis floerkei (F.Weber \& D.Mohr) L.Söderstr., De Roo \& Hedd. - Brotherus (1892): "in regione alpina montium Kasbek et Suarkom, Kobi ad fl. Terek" as Jungermannia lycopodioides var. Floerkei (W. M.) Lindb.

Pellia neesiana (Gottsche) Limpr. !

P. epiphylla (L.) Dum. - Brotherus (1892): "Lars ad fl. Terek".

Plagiochasma rupestre (J.R.Forst. \& G.Forst.) Steph. - Brotherus (1892): "Balta ad fl. Terek in fissuris humosis rupium calcar. regionis silvaticae media", as Aitonia rupestris Forst.

Plagiochila asplenioides (L.) Dumort. - Brotherus (1892): "in monte Suarkom ad fl. Didi Liachva, Balta, Lars et Kobi ad fl. Terek in monte Kasbek, reg. alp., ad mare glaciale Zei”. P. porelloides (Torr. ex Nees) Lindenb. !

Porella platyphylla (L.) Lindb. - Brotherus (1892): ! +"Balta, Lars et Kobi ad fl. Terek".

Radula complanata (L.) Dumort. - ! + Brotherus (1892): "Lars et Kobi ad fl. Terek in monte Kasbek ad mare glaciale Zei Var. Cucullifolia Steph. Ossetia, Lars ad fl. Terek ad rupes regionis silvaticae media".

R. lindenbergiana Gottsche ex C.Hartm.- Brotherus (1892): "Lars et Kobi ad fl. Terek", as Radula lindenbergii Gottsche.

Reboulia hemisphaerica (L.) Raddi. - Brotherus (1892): "Kobi ad fl. Terek".

Riccia sorocarpa Bish. - Brotherus (1892): "Kobi ad fl. Terek in fissuris humosis rupium regionis silvaticae superioris"

R. bifurca Hoffm. - Brotherus (1892): "Lars ad fl. Terek in fissuris humosis rupium regionis silvaticae media".

Scapania aequiloba (Schwägr.) Dumort. - Brotherus (1892): "inter Balta ad fl. Terek", as Martinellia aequiloba (Schwägr.) Lindb.

S. aspera M.Bernet \& Bernet - Brotherus (1892): Lars ad fl. Terek, as Martinellia aspera Bern.

S. irrigua (Nees) Nees !

S. cf. obcordata (Berggr.) S.W.Arnell!

Schistochilopsis incisa (Schrad.) Konstant. - Brotherus (1892):

Kobi ad fl. Terek, as Jungermannia incisa Schrad.

Solenostoma caucasicum (Váňa) Konstant. !

S. confertissimum (Nees) Schljakov!

Sphenolobus minutus (Schreb.) Berggr. !

Trilophozia quinquedentata (Huds.) Bakalin! + Brotherus (1892): "Lars ad f1. Terek, in monte Kasbek, reg. alp., in valle fl. Ardon et ad Zei”, as Jungermannia quinquedentata Huds. 